Acadiensis

Journal of the History of the Atlantic Region

ACADIENSIS

Revue d'histoire de la région Atlantique

\title{
A Region in Retrospective: The History of Atlantic Canada, 2009-2019
}

\section{Lachlan Mackinnon}

Volume 48, numéro 2, automne 2019

URI : https://id.erudit.org/iderudit/1067776ar

Aller au sommaire du numéro

Éditeur(s)

Department of History at the University of New Brunswick

ISSN

0044-5851 (imprimé)

1712-7432 (numérique)

Découvrir la revue

Citer cet article

Mackinnon, L. (2019). A Region in Retrospective: The History of Atlantic Canada, 2009-2019. Acadiensis, 48(2), 230-240. d'utilisation que vous pouvez consulter en ligne. 


\section{A Region in Retrospective: The History of Atlantic Canada, 2009-2019}

REGION IS A SLIPPERY IDEA. From its earliest iteration at the turn of the century, David Russell Jack's magazine Acadiensis concerned itself with the study of the Maritimes from a geographical perspective. With the revival of the journal in 1971, Newfoundland and Labrador were introduced as key areas of interest for scholars of the now-expanded Atlantic region. In the journal's first essay, entitled "Acadiensis II," Philip Bucker describes its focus as encompassing "not only the Maritime Provinces and Newfoundland, but also Gaspésia and Maine with further extensions into Central Canada and Northern New England." The impetus for a journal dedicated to this area emerged out of a historiographical suspicion of nationally focused historical narratives that ignored regional concerns and produced a collective antipathy towards the sense, famously expressed by Frank Underhill, that "nothing, of course, ever happens" in the Maritimes. ${ }^{2}$

The assumption of a coherent Atlantic region that conforms with the boundaries of political geography has also inspired calls for political action. Jack, in the earliest years of the original Acadiensis, was a proponent of Maritime Union. ${ }^{3}$ Ernie Forbes argued in 1979 that the Maritime Rights Movement, the regional flavour of the social gospel, and working class activism in places like industrial Cape Breton revealed a radical sense of regionalism that emboldened various forms of resistance to structural decline. ${ }^{4}$ This vision of the Atlantic region has also invigorated calls for political action from more conservative perspectives. A future union of the region's provinces, whether under a Maritime Union or Atlantic Union model, would - under this line of argument - reduce wasteful inefficiencies that go hand-in-hand with operating three (or four) distinct provinces. Why bother maintaining such

Philip Buckner, "Acadiensis II," Acadiensis 1, no. 1 (Autumn 1971): 8.

2 David Frank, "Public History and the People's History: A View from Atlantic Canada," Acadiensis 32, no. 2 (Spring 2003): 126.

3 Buckner, "Acadiensis II," 7.

4 Ernest R. Forbes, Maritime Rights: The Maritime Rights Movement, 1919-1927 (Montreal and Kingston: McGill-Queen's University Press, 1979), x. 
arbitrary borders, when - in the words of Conservative Senator Stephen Greene - "provincial boundaries are artificial. ... They divide a group of people ... who have the same, or very similar, ethnicity and histories, and who have very common problems and aspirations?"' Whatever the fate of such schemes, their continued relevance lends veracity to the assertion that Atlantic Canadians have "increasingly come to share an angle of vision regarding the world they inhabit."'

Since its founding in 1971, the revived Acadiensis has served as a forum for scholars to reflect upon how the region has been expressed through various areas of study. Class, gender, and race were, of course, explored - with an implicit understanding that their expression in the region is distinguished, in some way, from the broader Canadian experience. In 2000, Ian McKay published his modestly titled “A Note on 'Region' in Writing the History of Atlantic Canada," wherein he reflects upon the historical usage of the term at the turn of the 21st century. Recognizing five general themes, he identifies shortcomings in each and calls for regional historians to question "what 'region' - this 'region' we construct in the present and in our heads, to capture the elusive patterns of the past - may come to mean in our work and in our practice."

Based upon a close reading of Acadiensis and a survey of monographs published on subjects germane to "the Atlantic region" between 2009 and 2019, it is clear that the most transformative work currently being done in the field has responded to this question originally posed by McKay. This is visible in a number of areas, but for the purposes of this reflection I will focus on just three: the re-consideration of "region" as a contested space that encompasses Indigenous and other ways of knowing historical landscapes and places; the recognition that Atlantic Canada has been naturalized as a category of analysis both due to its position vis-à-vis other geographies of Canadian and international capitalism and as a result of periodization within our fields of study; and the utilization of the Atlantic region as a lens through which it becomes possible to understand environmental change in the longue durée.

5 John Ibbitson, "The Maritime Provinces Are Broke. If Union Is Not the Answer, What Is?" Globe and Mail, 4 December 2012.

6 Margaret Conrad and James Hiller, Atlantic Canada: A History, 2nd ed. (Toronto: Oxford University Press, 2010), viii.

$7 \quad$ The five categories that McKay identified at the turn of the 21st century were the naturalized region (bounded by political geography), the structural-functionalist region (utilized in much of the literature on regional underdevelopment), the socio-cultural sense of region, the Atlantic region as part of the national myth-symbol complex, and the region as an incubator for Gramscian organic intellectuals and other new ideas. See lan McKay, "A Note on 'Region' in Writing the History of Atlantic Canada," Acadiensis 29, no. 2 (Spring 2000): 101. 
One of the most significant ways that our consideration of region has opened up in the last ten years is through the work of Indigenous and settler scholars who have taken seriously the idea of moving beyond the boundaries of "Atlantic Canada" as a conceptual framework to explore our regional geography through alternative ways of knowing. This is clearly visible in the work of John Reid, who challenges a straightforward narrative of Indigenous dispossession by the Maritime colonies. Instead, Reid contextualizes the 18th century supplanting of Mi'kmaw and Wulstukwik territory within a broader discussion of the treaties and their related obligations. With no formal surrender of land, Indigenous claims to the territories in question were by no means extinguished despite the perceptions of colonial authorities and, later, the Canadian government. ${ }^{8}$ Mercedes Peters further explores this elsewhere in this forum, but the foundational point is that Mi'kma'ki - the Mi'kmaw territory encompassing much of the Maritime Provinces, Newfoundland, the Gaspé, and the Gulf Islands - remains in existence as a political, and not simply a conceptual, entity. ${ }^{9}$

What would it mean to write regional history that is fundamentally centred upon Mi'kma'ki, to use the Mi'kmaw example, instead of "Atlantic Canada?"” This cuts to the heart of some of the questions about region that authors at Acadiensis have been asking since J.M.S. Careless postulated about the value of region-building in his 1969 piece, "Limited Identities in Canada." ${ }^{11}$ Certainly, this sort of history is possible - but it requires recognizing the close connection between Mi'kmaw culture and territorial landscapes (weji-squalia'timk) and the continued existence of these relationships up to and including the present day. ${ }^{12}$

8 John Reid, "Empire, the Maritime Colonies, and the Supplanting of Mi'kma'ki/Wulstukwik, 17801820," Acadiensis 38, no. 2 (Summer/Autumn 2009): 81.

9 Territorial distinctions between Mi'kma'ki and Wulstukwik territory were taken from Trudy Sable and Bernie Francis, The Language of this Land, Mi'kma'ki (Sydney, NS: Cape Breton University Press, 2012), 16, and Reid, "Empire, the Maritime Colonies and the Supplanting of the Mi'kmaq/Wulstukwik," 81n4. See also Mercedes Peters, "The Future is Mi'kmaq: Exploring the Merits of Nation-Based Histories as the Future of Indigenous History in Canada," Acadiensis 48, no. 2 (Autumn/automne 2019): 206-16 and, for a comparable Wulstukwik example, see Micah A. Pawling, "Wəlastəkwey (Maliseet) Homeland: Waterscapes and Continuity within the Lower St. John Valley, 1784-1900," Acadiensis 46, no. 2 (Summer/Autumn 2017): 5-34.

10 The question is related to increased prevalence of histories focusing on the postConfederation experience of the Maritime First Nations and Inuit. See, for example, Martha Walls, "Confederation and Maritime First Nations," Acadiensis 46, no. 2 (Summer/Autumn 2017): 155-76, and Stephen Hay, "How to Win Friends and Trade with People: Southern Inuit, George Cartwright, and Labrador Households, 1763-1809," Acadiensis 46, no. 2 (Summer/Autumn 2017): 35-58.

11 David Frank, "Acadiensis, 1901 and 1999," Canadian Review of American Studies 30, no. 3 (Winter 2000): 368.

12 Sable and Francis, Language of this Land, 17. 
It requires the recognition that "we are all Treaty people" and the development of what Mary-Ellen Kelm describes as "an altered historical consciousness ... that understands the treaties as relational - as intellectual meeting points between two (or more) ontologies." ${ }^{13}$

Stephen Augustine describes the historical experience of the Mi'kmaq in Mi'kma'ki as one of "negotiating for life and survival" in the realms of environment, spirituality, and - later - "peace and friendship" with settler populations. ${ }^{14}$ The experience of treaty negotiations - while deeply political in their intersection with colonial systems of governance - was rooted also in longstanding understandings of life in Mi'kma'ki. Peters's essay explores, in an in-depth way, much of the work in this field, but looking to the future of historical study in the Atlantic region it appears that questions of this nature have much more to offer. ${ }^{15}$ It is gratifying to see historians grappling seriously with the question of what it means to do "trans-national" histories of places that exist in the same geographical space.

In the case of Atlantic Canada/Mi'kma'ki - or Cape Breton Island/ Unama'ki in the case of my work - this requires exploring how both settler and Indigenous perceptions of space and place developed in conversations within and between cultures and in the face of colonial and capitalist expansionism. ${ }^{16}$ In a sense, this is exactly the approach that is taken by Jeffers Lennox in Homelands and Empires. With the expansion of European colonialism into northeastern North America - relying as it did upon imperial "geographic fictions called Nova Scotia and Acadie" - Lennox maps how settlers conceptualized these spaces in particular ways that were contrary to - and with an implicit threat towards - Indigenous notions of homeland. ${ }^{17}$ Likewise, the visibility of multiple place-identities in conversation - and conflict - is at

13 Mary Ellen Kelm, "Living as Treaty People: Lessons from Mi'kma'ki and Beyond," Acadiensis 43, no. 1 (Winter/Spring 2014): 185.

14 Stephen J. Augustine, "Negotiating for Life and Survival," in Living Treaties: Narrating Mi'kmaw Treaty Relations, ed. Marie Battiste (Sydney, NS: Cape Breton University Press, 2016 ), 17.

15 Peters, "Future is Mi'kmaq."

16 William Wicken and Martha Walls have already applied this sort of approach in their examinations of the treaties; see William Wicken, The Colonization of Mi'kmaw Memory and History, 1794-1928: The King v. Gabriel Sylliboy (Toronto: University of Toronto Press, 2012) and Martha Walls, No Need of a Chief for this Band: The Maritime Mi'kmaq and Federal Electoral Legislation, 1899-1951 (Vancouver: University of British Columbia Press, 2010). It is also visible in Ruma Chopra, "Maroons and Mi'kmaq in Nova Scotia, 1796-1800," Acadiensis 46, no. 1 (Winter/ Spring 2017): 5-23.

17 Jeffers Lennox, Homelands and Empires: Indigenous Spaces, Imperial Fictions, and Competition for Territory in Northeastern North America, 1690-1763 (Toronto: University of Toronto Press, 2017), 4. 
the centre of Tshaukuesh Elizabeth Penashue's Nitinikiau Innusi: I Keep the Land Alive. Penashue places these conflicts in the context of modern politics, deftly tracing her own memories of anti-NATO protests during the $1980 \mathrm{os}$ and 1990 os by members of the Innu community in Labrador and connecting them directly to Innu conceptualizations of homeland. ${ }^{18}$ Such examples are instructive, and chart a path towards a reconsideration of region that begins to take seriously the voices of groups whose regional identities differ significantly from the rigid geo-spatial boundaries of Atlantic Canada. This represents another stage of development from the initial Acadiensis generation of social historians beginning in the 1970s, who sought to re-configure the history of the Maritimes and the Atlantic region generally to include the voices of "subaltern" groups.

Of course, such approaches also fit within the scope of more recent historiography. P.D. Clarke, for instance, described the significance of multiple place-identities that exist within the same geographical space in his 2000 Acadiensis article "L'Acadie Perdue." For Clarke, previous articulations of regional history had failed to account for the region as it was understood by Acadians - as Acadie - that is, as "two nations warring in the bosom of a single [region]." "19 Ronald Rudin's work on the displacement of Acadian populations from the land of the Kouchibouguac National Park is another example, revealing the complex interplay between culture, language, landscape, and memory. While this example is perhaps more local than "regional" in scope, the nature of the contestations that are at the heart of the Kouchibouguac story are the same as those that I hope will continue to inspire the study of this aspect of regional history more generally. ${ }^{20}$

While the underdevelopment paradigm, sometimes termed the "structuralfunctionalist" approach, has been subdued in recent historiography, there remains a recognition that the region was naturalized by the fluctuations of mercantile, colonial, and capitalist forces of production, relationships, and social organizations. ${ }^{21}$ The Atlantic region of northeastern North America

18 Tshaukuesh Elizabeth Penashue, Nitinikiau Innusi: I Keep the Land Alive (Winnipeg: University of Manitoba Press, 2019).

19 P.D. Clarke, "L'Acadie Perdue: Or, Maritime History's 'Other,"' Acadiensis 30, no. 1 (Autumn 2000): 90.

20 For further articulation of this point, see the discussion of multiple perspectives of the city of Moncton during the 1970s in Ronald Rudin, Kouchibouguac: Removal, Resistance, and Remembrance at a Canadian National Park (Toronto: University of Toronto Press, 2016), 226.

21 Jerry Bannister, "Atlantic Canada in an Atlantic World? Northeastern North America in the Long 18th Century," Acadiensis 43, no. 2 (Summer/Autumn 2014), 4-5. 
developed as a geographic and - later - a political entity that affected how its resources, both in terms of raw material and labour, were contested and controlled. In addition to this, as Fred Burrill describes elsewhere in this forum, there has been sustained attention from feminist and anti-racist scholars into the ways that the region's political economy sustains racial and gender-based hierarchies. ${ }^{22}$ Prevailing economic understandings about the region during the 2oth century also shaped how Maritimers and Atlantic Canadians were perceived in other parts of Canada and, simultaneously, how they came to understand themselves. ${ }^{23}$

Recent research in this area has taken care not to flatten regional issues of economy and class; urban and rural experiences are frequently examined as distinct but related poles of ongoing productive transformation. In his exploration of urban and rural production in the Maritimes, Alex Chernoff demonstrates that the major urban locales - Halifax and Saint John were capable of matching the productive capabilities of central Canadian "metropoles" as late as 1871. It was the combined higher proportion and lower productive capacity of rural manufacturers in the region, he argues, that contributed to the Maritimes lacklustre growth. ${ }^{24}$ While this complicates older master narratives that focus on metropolitan declensionism, it provides a worthwhile explanatory framework upon which we might begin to better understand what underdevelopment looks like - not only between regions in Canada, but also within them.

This theme has given rise to a series of recent histories that explore how conceptualizations of the Atlantic region have influenced historical actors, several of which examine this in relation to the motivations of regional capitalists. ${ }^{25}$ In the 1860 s men like T.D. Archibald and John Bourinot understood the Sydney coalfield - and the region into which it fit - not as a

22 Fred Burrill, "Redeveloping Underdevelopment: An Agenda for New Histories of Capitalism in the Maritimes," Acadiensis 48, no. 2 (Autumn/automne 2019), 179-89.

23 See Corey Slumkowski, Inventing Atlantic Canada: Regionalism and the Maritime Reaction to Newfoundland's Entry into Canadian Confederation (Toronto: University of Toronto Press, 2011) and Raymond Blake and Melvin Baker, Where Once They Stood: Newfoundland's Rocky Road Towards Confederation (Regina: University of Regina Press, 2019).

24 Alex Chernoff, "1871 Productivity Differentials and the Decline of the Maritime Manufacturing Sector," Acadiensis 43, no. 1 (Winter/Spring 2014): 88

25 Daniel Samson, The Spirit of Industry and Improvement: Liberal Government and RuralIndustrial Society, Nova Scotia, 1790-1862 (Montreal and Kingston: McGill-Queen's University Press, 2008); Béatrice Craig, Backwoods Consumers and Homespun Capitalists: The Rise of Market Culture in Eastern Canada (Toronto: University of Toronto Press, 2009); Donald Nerbas, Dominion of Capital: The Politics of Big Business and the Crisis of the Canadian Bourgeoisie, 1914-1947 (Toronto: University of Toronto Press, 2013). 
hinterland of North America, but as part of an expanding Anglo-sphere or British World system defined by the movement of capital and relationships of ownership and production. Such an understanding was difficult to displace, as even after Confederation "provincial elites remained wedded to the region's traditional Atlantic orientation within the British world system." ${ }^{26}$ By the mid2oth century, established tropes about the economic dysfunction of the region were affecting how its émigrés were being treated in other parts of the country - with some media accounts going so far as to deride them as a cause of "urban pathology."27 At the same time, and no doubt in response to such tropes, there was a broader political and cultural insistence on "industrial modernity" in the region, such as New Brunswick's experiment with the Bricklin or Joey Smallwood's "new industries" program in Newfoundland between 1949 and 1954, in order to counter the depressing regional stereotype. ${ }^{28}$

Much of the critical work in this area focuses on the social and cultural experience of Newfoundland and Labrador. Kurt Korneski argues that the contested space of Newfoundland's "treaty coast" witnessed the development of its lobster fishery in response to the capital-driven ecological depletion of lobster grounds in the Maritimes and Maine. ${ }^{29}$ This approach is clarified in his book Conflicted Colony, where Korneski notes that "Newfoundland reminds us that states truly are contingent and that historicizing borders involves not only areas in which boundaries have persisted but also those where states have faded from view or changed meaning." ${ }^{30}$ This understanding is also reflected in Carolyn Lambert's work on the earlier 19th century, when she argues Newfoundland was profoundly influenced by regional ideas about progressive modernism..$^{31}$ And there has also been increasing attention to the ways in which the region's economic history has been used to justify the enactment of political

26 Donald Nerbas, "Empire, Colonial Enterprise, and Speculation: Cape Breton's Coal Boom of the 1860s," Journal of Imperial and Commonwealth History 46, no. 6 (2018): 1086.

27 Greg Marquis, "Confederation's Casualties: The 'Maritimer' as a Problem in 1960s Toronto," Acadiensis 39, no. 1 (Winter/Spring 2010): 106.

28 Dimitry Anastakis, "Quest of the Volk(swagen): The Bricklin Car, Industrial Modernity, and New Brunswick," Acadiensis 43, no. 1 (Winter/Spring 2014): 92; Cerhard P. Bassler, "'Develop or Perish': Joseph R. Smallwood and Newfoundland's Quest for German Industry, 1949-1953," Acadiensis 25, no. 2 (Spring 1986): 94.

29 Kurt Korneski, "Development and Degradation: The Emergence and Collapse of the Lobster Fishery on Newfoundland's West Coast, 1856-1924," Acadiensis 41, no. 1 (Winter/Spring 2012): 24-5.

30 Kurt Korneski, Conflicted Colony: Critical Episodes in 19th Century Newfoundland and Labrador (Montreal and Kingston: McGill-Queen's University Press, 2016), 10.

31 Carolyn Lambert, "No Choice but to Look Elsewhere: Attracting Immigrants to Newfoundland, 1840-1890," Acadiensis 41, no. 2 (Summer/Autumn, 2012): 107. 
austerity programs in the present; as Sean Cadigan notes, "There has never been such a pressing need for historians to help create a public and counterhegemonic agenda of research and dissemination." ${ }^{2}$

Perhaps all of this begs the question of whether the treatment of Atlantic Canada or the Atlantic region as a particularly defined area of study within the scope of Canadian and international histories of capitalism presupposes a post-Confederation frame of reference. In other words, how does periodization shape the way the region is positioned within our historical writing? Certainly, pre-Confederation accounts of life in the Atlantic region abound, but it is also clear that the subjects of our writing would understand their lives in vastly different terms than we imagine when applying the regional lens. While this is an obvious point, it is worthwhile mentioning in order to highlight how the region - in much pre-Confederation research - seems to be more easily recognized as existing within and in connection to larger global forces. Anne Marie Lane Jonah's recent reflection on public history at the Fortress of Louisbourg, for instance, describes how the lives of two 18th century women were directly influenced by French colonial ambitions, the global history of slavery, and attitudes towards women within the Franco-sphere. ${ }^{33}$ Don Nerbas's work on Cape Breton Island within the English imperial context is expressed similarly, revealing the dimensions of what he terms an "empire effect" that saw London-based capital directed towards the industrialization of the Sydney coalfield as a result of the island's perceived position within the Anglo-sphere. ${ }^{34}$ These examples reflect how transformative the national policy framework was on the region when it came to not only political economy but also how we postConfederation historians continue to imagine the dimensions of this region that we study - a conceptualization that also continues to be impacted by the centrality of Confederation in 1867 and, in the case of Newfoundland and Labrador, Confederation in 1949.

The final area, for our purposes, where there remains transformative potential is in the study of ecology and the environment. Environmental historians frequently critique the unreflexive use of political geography as

32 Sean Cadigan, "History and Agendas in Atlantic Canada," Acadiensis 43, no. 2 (Summer/Autumn, 2014): 168.

33 Anne Marie Lane-Jonah, "Everywoman's Biography: The Stories of Marie Marguerite Rose and Jeanne Dugas at Louisbourg," Acadiensis 45, no. 1 (Winter/Spring 2016): 143-62.

34 Nerbas, "Empire, Colonial Enterprise, and Speculation." 
an organizing principle. ${ }^{35}$ It is perhaps unsurprising that it is from within this field that we uncover one of the most astute reflections upon the shifting nature of region-as-concept that has been published in the last decade. Claire Campbell and Robert Summerby-Murray complicate the naturalization of regional boundaries in their 2013 edited collection, Land \& Sea: Environmental History in Atlantic Canada; artificial political boundaries do not encompass the regional experience, the editors argue, nor do bioregional approaches - especially considering the area's great ecological diversity. Writing environmental history in (and of) the Atlantic region of Canada requires the simultaneous assessment and awareness of each of these scales and landscapes, ultimately providing what they call "a good vantage point: high enough to see patterns in the landscape, close enough to the ground to see the landmarks." ${ }^{36}$ This is underscored by Graeme Wynn's epilogue, wherein he notes the relative newness of the Maritimes or Atlantic Canada in comparison to "Acadia" or the territories of the Mi'kmaq, Wulstukwik, Passamaquoddy, and Beothuk. He notes "Each and all of these conceptual spaces were endowed with different meanings and occupied in different ways." ${ }^{37}$

Much of the environmental history of the region approaches the subject along these same lines. Teresa Devor provides an excellent example of this in her reflections upon the importance of what she calls "climate society interdependence." This is exhibited through the incorporation of the changing climate as a complicating variable within a broader history that examines the ways that climate impacts were either mitigated or compounded by a host of social, economic, and political factors unique to Atlantic Canada..$^{38}$ In considering the environmental geography of "The Maritime Peninsula," historians such as Devor, Brian Payne, Jason Hall, and others are able to

35 Laurel Sefton MacDowell, An Environmental History of Canada (Vancouver: University of British Columbia Press, 2012), 1-2, and see also Jennifer Bonnell, Reclaiming the Don: An Environmental History of Toronto's Don River Valley (Toronto: University of Toronto Press, 2014).

36 Claire Campbell and Robert Summerby-Murray, "Introduction: Environmental History in Atlantic Canada," in Land \& Sea: Environmental History in Atlantic Canada, ed. Claire Campbell and Robert Summerby-Murray (Fredericton: Acadiensis Press, 2013$), 4$.

37 Graeme Wynn, "Epilogue: Reflections on the Environmental History of Atlantic Canada," in Campbell and Summerby-Murray, Land \& Sea, 236.

38 Teresa Devor, "The Explanatory Power of Climate History for the 19th Century Maritimes and Newfoundland: A Prospectus," Acadiensis 43, no. 2 (Summer/Autumn 2014): 62. Others have explored the region through the lens of environmental activism; see, for example, Mark McLaughlin, "Green Shoots: Aerial Insecticide Spraying and the Growth of Environmental Consciousness in New Brunswick, 1952-1973," Acadiensis 40, no. 1 (Winter/Spring 2011): 3-23, and Sean Kheraj, "Scholarship and Environmentalism: The Influence of Environmental Advocacy on Canadian Environmental History," Acadiensis 43, no. 1 (Winter/Spring 2014): 195-206. 
connect with New England topics in transnational and comparative ways that might otherwise seem untenable. ${ }^{39}$ It strikes me that these connections are also developing beyond the pages of our journal or other publications, with the 2020 Atlantic Canada Studies Conference scheduled to occur - only for the second time in the conference's history - in Maine. ${ }^{40}$

Especially interesting in these recent histories is the emergent notion that the environment and ecology of the region contributes - and has been made to contribute - to the folkish pastoralism of the tourist economy. As Claire Campbell explains in her environmental history of Grand Pre, the view of the Annapolis Valley as "a site of beauty, fertility, and sentimental views of agriculture" came to exist during the 2oth century - part of an explicit effort to market the province's micro-climes to visitors. She notes that this is part of a pattern, describing similarly idyllic representations at play in the public history of places like Lunenburg and Prince Edward Island. ${ }^{41}$ Such work brings environmental historians into direct conversation with 2oth- and 21st-century political economy, public history, and deindustrialization. ${ }^{42}$ Others, like Will Langford, have begun to explore how organizations such as the Cape Breton Development Corporation (DEVCO) explicitly sought to tap into these public (mis)conceptions of environment and ecology through schemes such as the importation of Scottish sheep into Cape Breton in 1975 and 1976. ${ }^{43}$

If generalities are to be made, research has become more explicit about the use of region as an organizing principle. As McKay described in 2000: "What very likely began as a census category has since been naturalized as a regional inevitability and a focus of identity." 44 In reflecting upon alternative orientations of the region as an area of study, Indigenous and settler scholars have brought to bear questions about how multiple place-identities - each

39 Brian Payne, "The Environmental Historiography of the Maritime Peninsula," Acadiensis 45, no. 1 (Winter/Spring 2016): 164, and see also Jason Hall, "Maliseet Cultivation and Climactic Resilience on the Wəlastəkw/St. John River During the Little Ice Age," Acadiensis 44, no. 2 (Summer/Fall 2015): 3-25.

40 This iteration of the conference is being organized by University of New Brunswick-trained environmental historian Mark McLaughlin; the first Atlantic Canada Studies Conference that was held in Maine was in 1990.

41 Claire Campbell, "Idyll and Industry: Rethinking the Environmental History of Grand Pré, Nova Scotia," London Journal of Canadian Studies 31 (Autumn 2016): 14.

42 For explicit commentary on the environmental history of deindustrialization in relation to the Grand Banks cod fishery, see Dean Bavington, Managed Annihilation: An Unnatural History of the Newfoundland Cod Collapse (Vancouver: UBC Press, 2010). Development Corporation, 1972-1982," Acadiensis 46, no. 1 (Winter/Spring 2017): 24-48.

44 McKay, "Note on 'Region'," 96. 
with a host of associated political, economic, and social assumptions - have come to exist within the same physical space. The Mi'kma'ki example is instructive in this regard, in that its continued existence as a political and cultural entity allows for a re-consideration of "region" that steps beyond the boundaries imposed by the common definitions that rest upon 1867 (or 1949) as an organizing principle. This is also visible in the ways that recent studies of political economy have incorporated internal dynamics between urban and rural spaces as well as the position of the region within Canadian, North American, and global systems of capitalism. Finally, it is visible in the wealth of environmental histories that are being produced. Judging from the work conducted within the pages of Acadiensis between 2009 and 2019, the history of the Atlantic region continues to inspire original, insightful, and transformative research.

\section{LACHLAN MACKINNON}

LACHLAN MACKINNON est titulaire de la Chaire de recherche du Canada sur les collectivités postindustrielles (niveau 2) de I'Université Cape Breton. Ses recherches s'intéressent principalement aux expériences des travailleurs en matière de désindustrialisation et de développement régional au Canada atlantique. Son prochain livre, Closing Sysco, paraîtra chez University of Toronto Press en avril 2020.

LACHLAN MACKINNON is the Canada Research Chair (Tier II) in Post-Industrial Communities at Cape Breton University. His research focuses on workers' experiences of deindustrialization and regional development in Atlantic Canada, and his forthcoming book Closing Sysco will appear through the University of Toronto Press in April 2020. 